\title{
Modeling Big Sagebrush as a Fuel
}

WILLIAM H. FRANDSEN

\section{Abstract}

Sufficient data exist within the literature to allow the woody biomass of two subspecies of $A$ rtemisia tridentata, basin big sagebrush (Artemesia tridentata ssp. tridentata), and Wyoming big sagebrush (Artemesia tridentata ssp. wyomingensis), to be classified into 3 standard fuel size classes: 0 to $1 / 4$ inch $(0$ to $0.63 \mathrm{~cm}), 1 / 4$ to 1 inch $(0.64$ to $2.54 \mathrm{~cm})$, and 1 to 3 inches $(2.55$ to $7.62 \mathrm{~cm})$. Of primary significance to fire behavior is a technique wherein the biomass is modified and expressed as a fuel load referenced to the canopy area. A table relates the fuel load by size class to the height and canopy area of the shrub. Estimates of the average load by size class-necessary for predicting fire behavior-can be made for areas where the shrub dimensions and number densities are known. Those less interested in fire will find this table an easy-touse reference to the physical description of these shrubs. Although classification of the woody biomass by size class was a major result, regressions of the leaf and woody biomass on canopy area and height and regressions of canopy area on height are presented on a comparable basis for both subspecies. Regressions of biomass on height and canopy area suggest that wyomingensis is similar to tridentata up to a shrub height of $0.8 \mathrm{~m}$ where the biomass for similar crown dimensions increases 1.5 and 1.8 fold at greater heights.

A knowledge of fire behavior (flame length, rate of spread, intensity, etc.) of sagebrush is necessary to land managers desiring to manipulate the vegetation or control fire in the sagebrush plant community. In order to predict fire behavior it is further necessary to describe sagebrush as a fuel. That is, to describe the shrub in terms of its ability to burn, stripped of its biological description as a living plant. Factors describing a plant as fuel are biomass classified into leaf and woody fuel sizes, height, volume, bulk density, chemical properties, and moisture content. We will consider only the physical characteristics-biomass classified into leaf and woody fuel sizes, volume, bulk density - and relate them to the height and canopy area of two subspecies of big sagebrush. Finally, the application of these factors to a specific area rather than an individual shrub requires a knowledge of the number density of shrubs on the area.

Most big sagebrush (Artemisia tridentata) biomass studies relate the total woody biomass and the photosynthetic or leafy biomass to the crown dimensions of the plant (Harniss and Murray 1976, Rittenhouse and Sneva 1977, and Uresk and others 1977). This information is not sufficient to describe the fire behavior associated with the burning of big sagebrush because the woody biomass does not distinguish between twig sizes. The rate that an individual particle in the shrub gives off flammable gases in the presence of heat depends on the ratio of its surface area to its volume (Rothermel 1972). The ratio of the surface area to the volume of a branch or twig is inversely related to its diameter. Consequently, the distribution of branches and twigs by diameter classes is important to the description of big sagebrush as a fuel. Although primarily intended for those interested in viewing sagebrush as a fuel, the final tabular results offer the reader a quick assessment of the physical description of basin big sagebrush and Wyoming big sagebrush.

\footnotetext{
Author is research physicist, USDA Forest Service, Intermountain Forest and Range Experiment Station, Ogden, Utah, located at Northern Forest Fire Laboratory, Missoula, Mont.

Manuscript received November 16,1981
}

Brown (1976), recognizing the inadequacy of biomass studies to meet fuel modeling needs, investigated the biomass of shrubs classified into leaf and twig fuel size classes. The fuel size class is characterized in fire behavior modeling by its timelag constant expressed in hours and related to the rate at which it responds to humidity by absorbing or desorbing moisture (Fosberg 1970). The moisture content of small-sized particles responds quickly to humidity changes and they are characterized as short time lag fuels; larger particles require longer time lags. The 0 - to $0.63-\mathrm{cm}$ size class is called a th timelag fuel, the $0.64-$ to $2.54-\mathrm{cm}$ size class is called $10 \mathrm{~h}$, and the $2.255-$ to $7.62-\mathrm{cm}$ size class is called the $100 \mathrm{~h}$.

The biomass Brown measured was obtained from single branches of the shrub and related to the basal diameter of the stem. He also examined the distribution of diameters within each size class and obtained an average size for each size class interval so that the woody biomass could be partitioned into the fuel size classes mentioned.

Brown's data were obtained from big sagebrush with no distinction as to subspecies. I have used Brown's relationships for basin big sagebrush (A. tridentata spp. tridentata Nuttal) and Wyoming big sagebrush ( $A$. tridentata spp. wyomingensis Beetlc). I suggest that although the overall growth forms are different between subspecies, the leaf and woody biomass related to the basal diameter of a single stem is not significantly different, i.e., the biomass should correlate to the basal stem containing the xylem tissue on which it depends. This point has not been proven although it seems reasonable to assume that similar basal diameter cross sections would support similar woody and leaf biomasses.

The intent of this paper is to develop a characteristic basal diameter for the whole plant (subspecies of big sagebrush) that corresponds to its crown dimensions. The whole plant basal diameter can then be used to derive the woody biomass by size class, according to Brown (1976). Finally, the leaf biomass and the woody biomass classified into 3 fuel size classes for 2 subspecies of big sagebrush will be presented in tabular form related to the original crown dimensions of the plant expressed as height and canopy area. Land managers will be able to use these tabular results to obtain the biomass of big sagebrush (basin and Wyoming) expressed in fuel size classes from measurements of the shrub's height and canopy area.

\section{Method of Analysis}

Two sets of data were examined: basin big sagebrush and Wyoming big sagebrush. Data are identified below according to their sources.

$\begin{array}{ll}\text { Subspecies } & \text { Source } \\ \text { tridentata } & \text { Uresk and others (1977) } \\ \text { wyomingensis } & \text { Rittenhouse and Sneva (1977) }\end{array}$

Estimates of the leaf and woody biomass can be obtained from the crown dimensions according to the above sources. Uresk and others (1977) documented small particle masses (such as flowers, stalks) for basin big sagebrush. They have been excluded, however, as being seasonal; leaf mass alone is preferred. Furthermore, only leaf and woody mass are given for Wyoming big sagebrush.

Both data sets used the height of the plant and two crown dimensions in the horizontal plane: the greater width and the 
Table 1. Regression coefficients for equation 1, relating biomass to plant height and canopy area.

\begin{tabular}{|c|c|c|c|c|c|c|}
\hline \multirow[b]{2}{*}{ Subspecies } & & \multicolumn{3}{|c|}{ Regression coefficients } & \multirow[b]{2}{*}{$R^{2}$} & \multirow[b]{2}{*}{ Observations } \\
\hline & & $b_{0}$ & $b_{1}$ & $b_{2}$ & & \\
\hline tridentata & $\begin{array}{l}\text { Leaf } \\
\text { Woody }\end{array}$ & $\begin{array}{l}-0.8348 \\
-0.0664\end{array}$ & $\begin{array}{r}0.2042 \\
.8100\end{array}$ & $\begin{array}{r}1.2324 \\
.9535\end{array}$ & $\begin{array}{r}0.67 \\
.81\end{array}$ & $\begin{array}{l}20 \\
20\end{array}$ \\
\hline wyomingensis ${ }^{l}$ & $\begin{array}{l}\text { Leaf } \\
\text { Woody }\end{array}$ & $\begin{array}{l}-0.6750 \\
-0.2699\end{array}$ & $\begin{array}{l}.5553 \\
.7409\end{array}$ & $\begin{array}{l}1.1780 \\
1.7351\end{array}$ & $\begin{array}{l}.97 \\
.96\end{array}$ & $\begin{array}{l}26 \\
26\end{array}$ \\
\hline
\end{tabular}

1These data are in slight disagreement with Rittenhouse and Sneva (1977) because of the elimination of one questionable observation.

greatest dimension perpendicular to the greatest width. (The shrub is assumed to have an elliptical shape in the horizontal plane with these dimensions as the major and minor axes.) The leaf and woody biomass data were acquired from the authors of the two referenced sources and regressed on the height and canopy area. Height and canopy area were chosen because these independent variables have been used successfully to form strong predictive relationships. Furthermore, using the canopy area rather than the major and minor axes of the crown simplifies the final table for cataloging the fuel loads.

The regression relating biomass to canopy area and height is: where

$$
\mathrm{M}=10^{\mathrm{b}_{0}} \mathrm{~A}^{\mathrm{b}_{1}} \mathrm{H}^{\mathrm{b}_{2}}
$$

$M$ is the leaf or woody biomass in kilograms

$A$ is the canopy area in square meters

$H$ is the plant height in meters

and the constants $b_{0}, b_{1}$, and $b_{2}$ are regression coefficients. They are listed in Table 1 for both subspecies.

The development of a table relating the biomass to height and canopy area required that the canopy area be regressed on the height in order to obtain an appropriate range of canopy areas for selected shrub heights. The regression relation has the form:

$$
A=10^{c_{0}} \mathbf{H}^{c_{1}}
$$

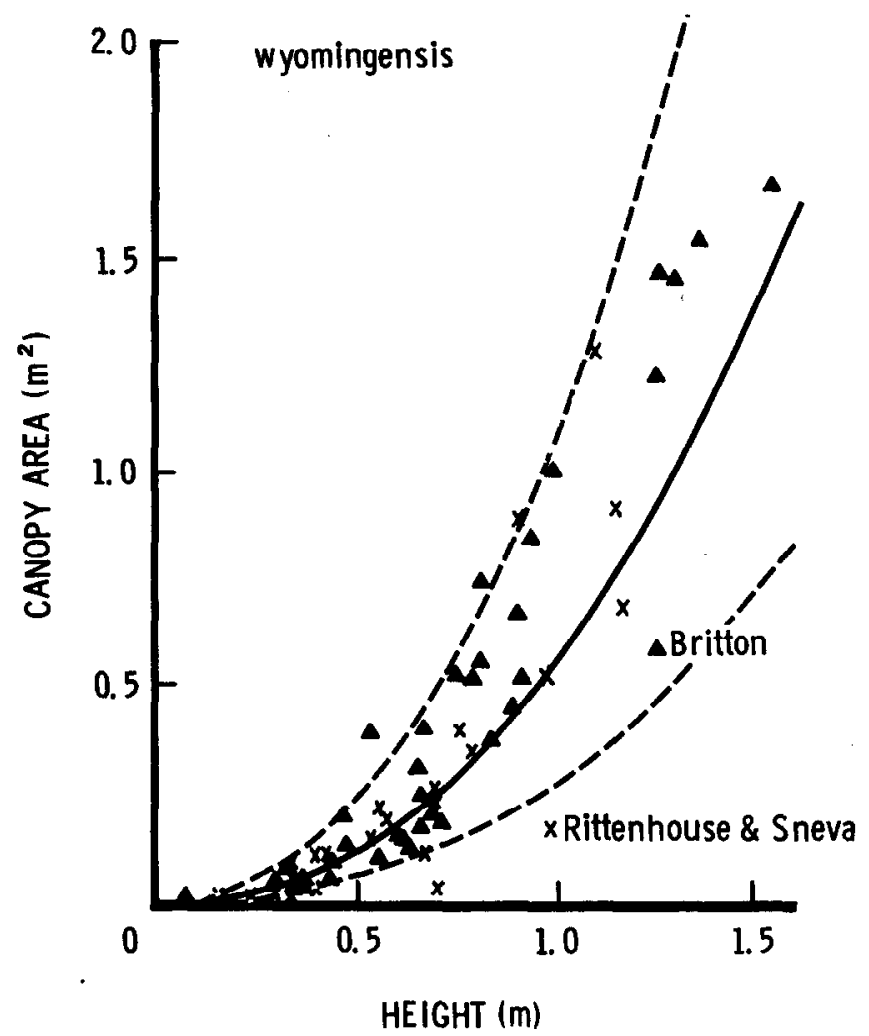

where the constants $c_{0}$ and $c_{1}$ are regression coefficients.

They are listed in Table 2 for both subspecies.

The data used to develop Table 2 are plotted in Figure 1. Three curves are shown for both subspecies. The central curve was obtained from Equation 2. The upper and lower curves form the boundaries of one standard deviation of displacement from estimates of the canopy area. Using the boundary curves we can obtain estimates of the range of areas, $\Delta \mathrm{A}$, associated with a selected range of shrub heights, as illustrated by the arrows in Figure 3. Each canopy area range within a selected shrub height range was subdivided into a set of intervals. The leaf and woody biomass for each area interval within a height range is then estimated from

Table 2. Regression coefficients for equation 2, relating canopy area to plant height.

\begin{tabular}{lcccc}
\hline & \multicolumn{2}{l}{ Regression coefficients } & & \\
\cline { 2 - 4 } Subspecies & $\mathrm{c}_{0}$ & $\mathrm{c}_{1}$ & $R^{2}$ & Observations \\
\hline tridentata & 0.8003 & 1.5254 & 0.54 & 867 \\
wyomingensis $^{I}$ & -.8471 & 2.2953 & .79 & 66 \\
\hline
\end{tabular}

'An additional 40 observations from Carlton Britton, Texas Tech University, Lubbock, are included with the wyomingensis data. The original data from Uresk and others (1977) includes 847 additional observations on the crown dimensions.

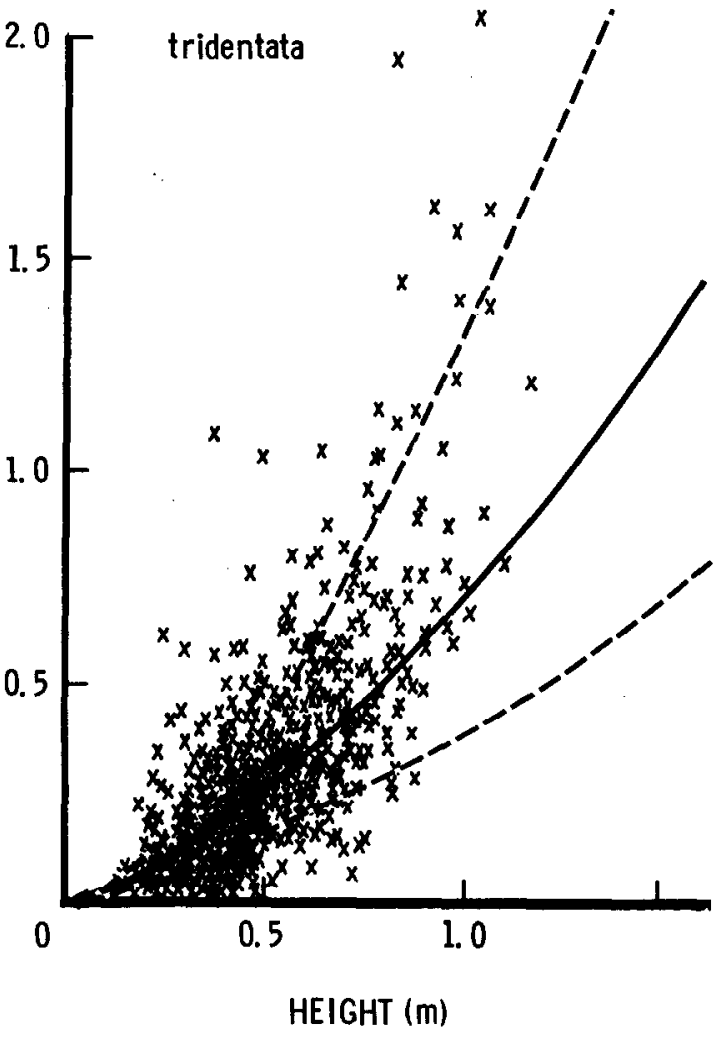

Fig. 1. Canopy area versus height for Wyoming big sagebrush (Artemisia tridentata wyomingensis) and basin big sagebrush (A. tridentata tridentata). The central curve represents the regression curve of the plotted data. The upper and lower curves represent one standard deviation from the regression line projected onto the canopy area. 


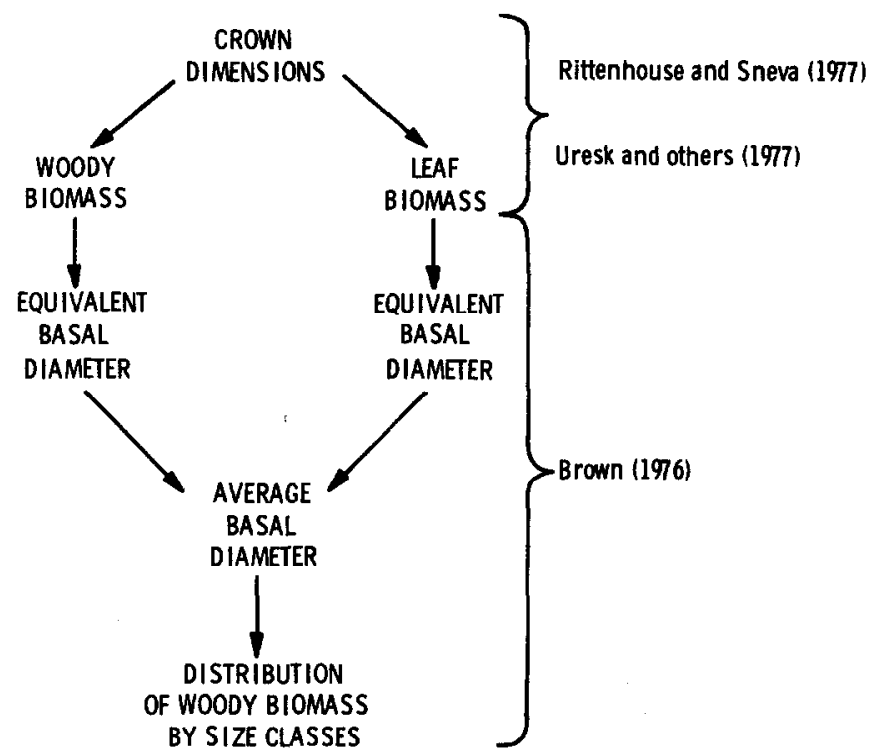

Fig. 2. Diagram illustrating the flow of information from the crown dimensions of sagebrush through its basal diameter to the final breakdown of its woody biomass by size class.

Equation I using the midpoints of the area interval and the overall height range.

Estimates of the basal stem diameter, D, of a sagebrush plant were obtained from an alternative form of Brown's regression model (James K. Brown, 1980, personal communication), as expressed below in equations (3) and (4).

$$
\begin{aligned}
& M_{e}=4.968 D^{1.888} \\
& M_{w}=18.52 D^{2.314}
\end{aligned}
$$

where

$\mathbf{M}_{e}=$ is the leaf biomass in grams

and

$M_{w}$ is the woody biomass in grams

$$
D \text { is the shrub basal diameter in centimeters. }
$$

In effect, the whole plant basal stem diameter was estimated from the crown dimensions as follows. Leaf and woody biomass were obtained from height and canopy area (Equation 1). Two diameters were then estimated: one from the leaf biomass, the other from the woody biomass (Equations 3 and 4). The diameters were averaged to obtain a single characteristic diameter. This diameter was then used to partition the woody biomass into its three fuel size classes ( $1 \mathrm{~h}, 10 \mathrm{~h}$, and $100 \mathrm{~h}$ ) according to Brown (ibid). Figure 2 summarizes these steps.

The relationships needed to partition the biomass into the 3 size classes were obtained by fitting curves to the graphical representations given by Brown. If the characteristic shrub basal stem diameter was less than or equal to $0.5 \mathrm{~cm}$ it was assigned completely to the Ih size class. If the diameter was equal to or greater than $0.5 \mathrm{~cm}$ but less than $2.0 \mathrm{~cm}$ part of the woody biomass will extend into the $10 \mathrm{~h}$ size class. They are partitioned according to the following fractions:

and

$$
F_{1}=D /(3.763 D-1.460)
$$

$$
F_{10}=1-F_{1}
$$

where

$$
\begin{aligned}
& F_{1}=\text { woody biomass fraction in the } 1 \mathrm{~h} \text { size class } \\
& F_{10}=\text { woody biomass fraction in the } 10 \mathrm{~h} \text { size class }
\end{aligned}
$$

If the diameter was equal to or greater than $2.0 \mathrm{~cm}$ but less than 7.0 $\mathrm{cm}$, the fraction $F_{1}$ remains unchanged,

$$
F_{10}=D /(4.095 D-5.154)
$$

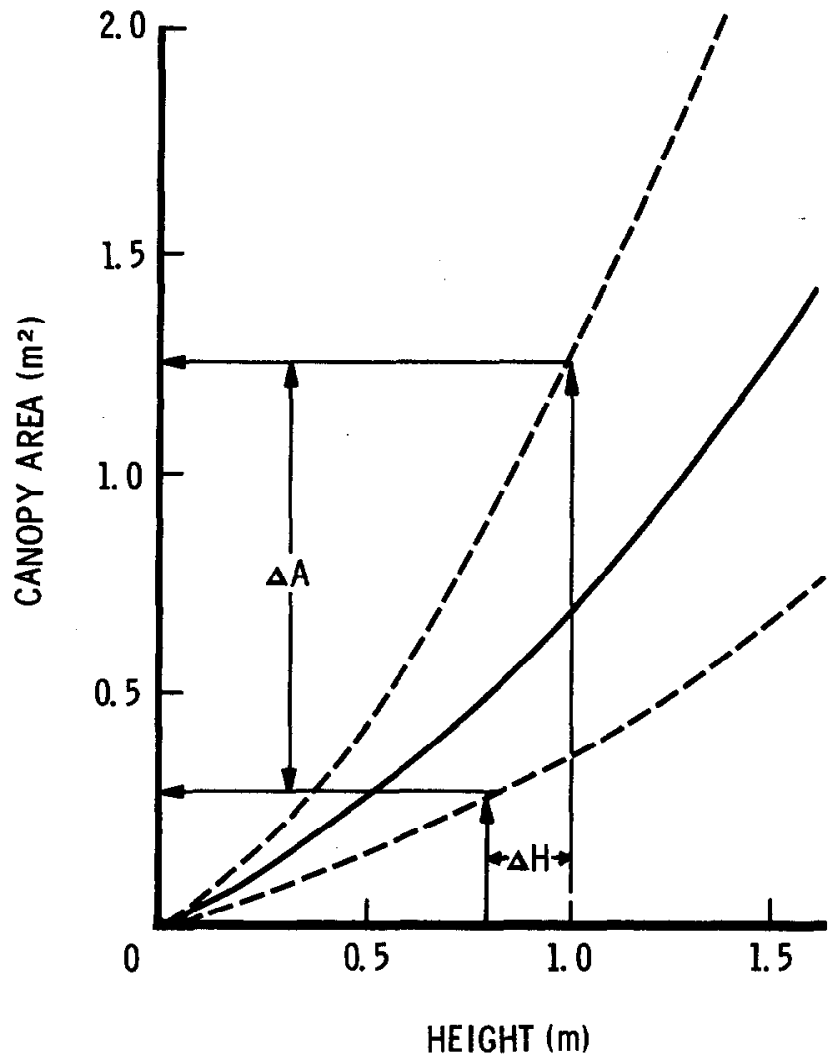

Fig. 3. The regression curve of the canopy area of basin big sagebrush versus height is expressed by the central curve. Two other curves are included that are one standard deviation above and below the regression curve. An appropriate range for the area, $\Delta A$, is obtained from the selected height range, $\Delta H$, by following the arrows as they intersect with the standard deviation curves.

and

where

$$
F_{100}=1-F_{1}-F_{10}
$$

$F_{100}=$ woody biomass fraction in the $100 \mathrm{~h}$ size class.

The resulting biomass of each size class was then converted to a fuel load by dividing it by the appropriate canopy area.

Two other descriptors of the shrub, the shrub's volume and the bulk density of the crown are important to the prediction of fire behavior in big sagebrush. The volume was obtained by assuming the shape to be an oblate spheroid generated by rotating the shrub's ellipse about the minor axis. The resulting volume is:

$$
\begin{aligned}
& \text { where } \\
& w_{1} \text { is the major axis in meters } \\
& w_{2} \text { is the minor axis in meters. }
\end{aligned}
$$

To allow for those instances where the shrub height is less than the major axis, a more representative volume was obtained by averaging the major axis $w_{1}$, and the shrub height, H. Substituting $\left(w_{1}+\right.$ H)/ 2 for $w_{1}$, we have:

$$
\mathrm{V}=\pi\left(\mathrm{W}_{1}+\mathrm{H}\right)^{2} \mathrm{~W}_{2} / 24
$$

The bulk density is an important descriptor of the fuel complex relating to the separation between particles, a relative measure of the distance the fire must jump without the intervention of crossed members to aid the spread of fire. It also relates to the ability of air to move through the fuel array. A smaller number implies less air resistance.

\section{Results}

The fuel loads for two subspecies of big sagebrush, basin and Wyoming, are compiled in Table 3. Both have similar fuel parame- 
Table 3. Fuel parameters for different height and canopy area ranges for individual shrubs of $A$ rtemisia tridentata tridentata followed by adjustments to obtain fuel parameters for $\boldsymbol{A}$. tridentata wyomingensis.

\begin{tabular}{|c|c|c|c|c|c|c|c|}
\hline \multirow[b]{2}{*}{$\begin{array}{l}\text { Height } \\
\text { (m) }\end{array}$} & \multirow[b]{2}{*}{$\begin{array}{c}\text { Canopy area } \\
\left(\mathrm{m}^{2}\right)\end{array}$} & \multicolumn{4}{|c|}{ Fuel load $\left(\mathrm{kg} / \mathrm{m}^{2}\right)$} & \multirow[b]{2}{*}{$\begin{array}{c}\text { Volume } \\
\left(\mathrm{m}^{3}\right)\end{array}$} & \multirow[b]{2}{*}{$\begin{array}{c}\text { Bulk density } \\
\left(\mathrm{kg} / \mathrm{m}^{3}\right)\end{array}$} \\
\hline & & Leaves & lh & $10 \mathrm{~h}$ & $100 \mathrm{~h}$ & & \\
\hline $0.4-0.6$ & $\begin{array}{r}0-0.05 \\
0.05-.10 \\
.10-.15 \\
.15-.20 \\
.20-.30 \\
.30-.45\end{array}$ & $\begin{array}{r}0.83 \\
.39 \\
.28 \\
.23 \\
.18 \\
.14\end{array}$ & $\begin{array}{r}0.47 \\
.34 \\
.29 \\
.27 \\
.25 \\
.22\end{array}$ & $\begin{array}{r}0.87 \\
.60 \\
.46 \\
.39 \\
.34 \\
.28\end{array}$ & $\begin{array}{l}0 \\
.10 \\
.18 \\
.20 \\
.22 \\
.22\end{array}$ & $\begin{array}{l}0.010 \\
.026 \\
.042 \\
.085 \\
.13 \\
.13\end{array}$ & $\begin{array}{l}5.5 \\
4.2 \\
3.6 \\
3.0 \\
2.5 \\
2.5\end{array}$ \\
\hline $0.6-0.8$ & $\begin{array}{l}.05-.10 \\
.10-.20 \\
.20-.30 \\
.30-.50 \\
.50-.75\end{array}$ & $\begin{array}{l}.59 \\
.38 \\
.28 \\
.21 \\
.15\end{array}$ & $\begin{array}{l}.52 \\
.43 \\
.37 \\
.34 \\
.30\end{array}$ & $\begin{array}{l}.76 \\
.57 \\
.47 \\
.40 \\
.34\end{array}$ & $\begin{array}{l}.38 \\
.42 \\
.42 \\
.41 \\
.39\end{array}$ & $\begin{array}{l}.039 \\
.072 \\
.12 \\
.19 \\
.30\end{array}$ & $\begin{array}{l}4.4 \\
3.8 \\
3.3 \\
2.9 \\
2.5\end{array}$ \\
\hline $0.8-1.0$ & $\begin{array}{l}.10-.20 \\
.20-.40 \\
.40-.60 \\
.60-.90 \\
.90-1.20\end{array}$ & $\begin{array}{l}.51 \\
.34 \\
.24 \\
.20 \\
.14\end{array}$ & $\begin{array}{l}.45 \\
.39 \\
.35 \\
.32 \\
.30\end{array}$ & $\begin{array}{l}.56 \\
.46 \\
.40 \\
.36 \\
.33\end{array}$ & $\begin{array}{l}.51 \\
.49 \\
.46 \\
.44 \\
.42\end{array}$ & $\begin{array}{l}.097 \\
.18 \\
.30 \\
.46 \\
.66\end{array}$ & $\begin{array}{l}3.3 \\
2.8 \\
2.4 \\
2.1 \\
1.9\end{array}$ \\
\hline $1.0-1.2$ & $\begin{array}{r}.20-.30 \\
.30-.50 \\
.50-.70 \\
.70-1.00 \\
1.00-1.30 \\
1.30-1.60\end{array}$ & $\begin{array}{l}.47 \\
.35 \\
.28 \\
.19 \\
.15 \\
.12\end{array}$ & $\begin{array}{l}.48 \\
.44 \\
.41 \\
.37 \\
.35 \\
.34\end{array}$ & $\begin{array}{l}.56 \\
.50 \\
.44 \\
.41 \\
.38 \\
.36\end{array}$ & $\begin{array}{l}.62 \\
.59 \\
.57 \\
.54 \\
.52 \\
.50\end{array}$ & $\begin{array}{r}.20 \\
.30 \\
.45 \\
.63 \\
.86 \\
1.11\end{array}$ & $\begin{array}{l}2.9 \\
2.6 \\
2.3 \\
2.1 \\
1.9 \\
1.7\end{array}$ \\
\hline
\end{tabular}

Table modifications for $A$. tridentata wyomingensis:

\begin{tabular}{rrlllll}
\hline \multicolumn{1}{c}{ Applicable range } & \multicolumn{5}{c}{ Column multipliers } \\
\hline $0.4-0.6$ & $0-0.45$ & 1 & 1 & 1 & 1 & 1 \\
$.6-.8$ & $0.05-.75$ & 1 & 1 & 1 & 1 & 1 \\
$.8-1.0$ & $.10-1.20$ & 1 & 1.5 & 1.5 & 1.5 & 1 \\
$1.0-1.2$ & $.20-.70$ & 1 & 1.8 & 1.8 & 1.8 & 1 \\
\hline
\end{tabular}

'See introduction of this paper.

$\begin{array}{llll}\text { Load class } \ldots & \text { ih } & 10 \mathrm{~h} & 100 \mathrm{~h} \\ \text { Size range } . . & 0 \text { to } 0.63 & 0.64 \text { to } 2.54 \mathrm{~cm} & 2.55 \text { to } 7.62 \mathrm{~cm}\end{array}$

ters for height ranges 0.4 to $0.6 \mathrm{~m}$ and 0.6 to $0.8 \mathrm{~m}$. However, results for height ranges 0.8 to $1.0 \mathrm{~m}$ and 1.0 to $1.2 \mathrm{~m}$ show a greater woody fuel load for Wyoming big sagebrush. Rather than develop an extra table for Wyoming big sagebrush, Table 3 was modified to give the results for that subspecies. Modifiers-multipliers-are given at the foot of Table 3 to account for changes in the results. Multipliers for height ranges 0.4 to $0.6 \mathrm{~m}$ and $0.6 \mathrm{~m}$ to $0.8 \mathrm{~m}$ are, of course, 1.0 because the results of both subspecies are identical over that range.

Fuel load, volume, and bulk density for a specific shrub of one of the two subspecies are obtained by using the appropriate height range and area interval in the table. The area is computed according to the equation:

$$
A=\pi w_{1} w_{2} / 4
$$

The height is the maximum height of the shrub in meters. If the height is greater than $0.8 \mathrm{~m}$, the load, volume, and bulk density for basin big sagebrush are adjusted by the multipliers listed at the foot of Table 3 to obtain the corresponding parameters for Wyoming big sagebrush, e.g., if the height is within the range 1.0 to $1 . \mathrm{m}$, the woody loads for basin big sagebrush are multiplied by 1.8. Note also that Wyoming big sagebrush results are limited to canopy areas within the range .20 to $.70 \mathrm{~m}^{2}$ within the height range 1.0 to $1.2 \mathrm{~m}$.

\section{Discussion}

Martin and others (1981) give the live and dead load by size class for big sagebrush having an average height of $0.60 \mathrm{~m}$ and an average crown diameter of $0.75 \mathrm{~m}$. Converting the crown diameter to canopy area $\left(\pi(0.75 / 2)^{2} \mathrm{~m}^{2}=0.44 \mathrm{~m}^{2}\right)$ allows a comparison between the combined live and dead loads of Martin and others (1981) and the loads (also combined live and dead) presented in Table 3. Because the comparison height lies between the height ranges of $0.4-0.6 \mathrm{~m}$ and $0.6-0.8 \mathrm{~m}$ in Table 3 , it is necessary to interpolate. A numerical comparison is given in Table 4. Note that the comparison is made at $100 \%$ canopy cover, the load of a single plant projected onto the ground.

Table 4. A comparison of the loads by size class between Martin and others (1981) and Table 3.

\begin{tabular}{lcccc}
\hline \hline & \multicolumn{4}{c}{ Fuel load $\left(\mathrm{kg} / \mathrm{m}^{2}\right)$} \\
\cline { 2 - 5 } Data source & Leaves & lh & $10 \mathrm{~h}$ & $100 \mathrm{~h}$ \\
\hline Martin and & & & & \\
others & 0.14 & 0.53 & 0.46 & 0.24 \\
Table 3 & 0.18 & 0.28 & 0.34 & 0.32 \\
\hline
\end{tabular}

The comparison in the leaf size class is excellent while the woody size classes show good agreement. In general, the agreement is encouraging considering the wide standard deviation, $0.31 \mathrm{~m}$, for both the crown height, $0.60 \mathrm{~m}$, and the crown diameter, $0.75 \mathrm{~m}$ and the different origins of data.

With Table 3, it is possible to obtain the fuel load by size class for predicting fire behavior in basin big sagebrush and Wyoming big 
Table 5. Example average load by size class for basin big sagebrush (tridentata) and Wyoming big sagebrush (wyomingensis) within the height range 0.8 to $1.0 \mathrm{~m}$, area interval 0.4 to $0.6 \mathrm{~m}^{2}$, and number density $0.7 \mathrm{~m}^{-2}$.

\begin{tabular}{lcccc}
\hline & \multicolumn{4}{c}{ Fuel load $\left(\mathrm{kg} / \mathrm{m}^{2}\right)$} \\
\cline { 2 - 5 } Subspecies & Leaves & \multicolumn{1}{c}{$\mathrm{h}$} & $10 \mathrm{~h}$ & $100 \mathrm{~h}$ \\
\hline tridentata & 0.084 & 0.12 & 0.14 & 0.16 \\
wyomingensis & .13 & .18 & .21 & .24 \\
\hline
\end{tabular}

sagebrush given the total height, canopy area, and the number per unit area within each crown dimension over a range of crown heights from 0.4 to $1.2 \mathrm{~m}$ and canopy areas from 0.05 to $1.6 \mathrm{~m}^{2}$. For example, consider the following:

$\begin{array}{ll}\text { Height range } & 0.8 \text { to } 1.0 \mathrm{~m} \\ \text { Area interval } & 0.4 \text { to } 0.6 \mathrm{~m}^{2} \\ \text { Number density } & 0.7 \mathrm{~m}^{-2}\end{array}$

The average canopy area per shrub is $0.5 \mathrm{~m}^{2}$. The average percent coverage is the average canopy area times the number density of shrubs.

$$
\text { Percent canopy coverage }=(0.5)(0.7) \times 100=35 \% .
$$

Since only $35 \%$ of the area is covered by shrubs, we must reduce the indvidual shrub load to $35 \%$ of the individual tabular load; that is, the average load is spread over a larger area. For Wyoming big sagebrush, the final load is increased by a factor of 1.5 (given at the foot of Table 3). The final load breakdown for the above example is given in Table 5.

Brown (1982) used data of a similar form for sagebrush that allowed him to predict fire behavior in sagebrush. Results from 3 prescribed fires showed reasonably good agreement between observed and predicted rates of spread. There is potential to manage big sagebrush with fire. However, it requires that we view sagebrush as a fuel.

\section{Publications Cited}

Brown, James K. 1976. Estimating shrub biomass from basal stem diameters. Can. J. Forest Res. 6:153-158.

Brown, James K. 1982. Fuel and fire behavior prediction in big sagebrush. Res. Pap. INT-290. Ogden, Utah: USDA, Forest Service, Intermountain Forest and Range Exp. Sta.

Fosberg, M. 1970. Drying rates of heartwood below fiber saturation. Forest Sci. 16:57-63.

Harniss, Roy 0., and Robert B. Murray. Reducing bias in dry leaf weight estimates of big sagebrush. J. Range Manage. 29:430-432.

Martin, Robert E., David W. Frewing, and James L. McClanahan. 1981. Average biomass of four northwest shrubs by size class and crown cover. Res. Note PNW-374. Portland, Ore. USDA, Forest Service, Pacific Northwest Forest and Range Exp. Sta.

Rittenhouse, L.R., and F.A. Sneva. 1977. A technique for estimating big sagebrush production. J. Range Manage. 30:68-70.

Rothermel, R.C. 1972. A mathematical model for predicting fire spread in wildland fuels. Res. Pap. INT-115. Ogden, UT: USDA, Forest Service, Intermountain Forest and Range Exp. Sta.

Uresk, D.W., R.O. Gilbert, and W.H. Rickard. 1977. Sampling big sagebrush for phytomass. J. Range Manage. 30:311-314.

\section{Rangeland Plant Physiology}

edited by Ronald A. Sosebee

$\begin{array}{ll}\star 290 \text { pages } & \star \text { extensive bibliographies } \\ \star \text { illustrated } & \star \$ 14.50 \text { postpaid } \\ \star \text { soth cover perfect bound } & \end{array}$

Of particular interest to all who study, manage, or simply admire plant life, the book is a valuable college text supplement and a reference source for range managers and technicians. Each chapter, authored by one or more authorities in the field, examines in considerable depth one aspect of plant physiology. Chapters include:

1. Gas Exchange and Photosynthetic Pathways in Range Plants; II Carbohydrate Translocation in Pange Plants; III. Distribution and Utilization of Carbohydrate Reserves in Range Plants; IV. Water Relations of Range Plants; V. Salinity Effects on Range Plants; VI. Seed Physiology; VII. Plant Growth Regulators; VIII. Mineral Cycling in Rangeland Ecosystems; IX. Developmental Morphology and Management Implications.

Society for Range Management 2760 Weat Fith Ave. Denver, Colorado 80204 